\title{
- \\ PCR with End Trimming and Cassette Ligation: A Rapid Method to Clone Exon-Intron Boundaries and a 5'-Upstream Sequence of Genomic DNA Based on a CDNA Sequence
}

\author{
Hiroyuki Iwahana, Toshiyuki Tsujisawa, Rumi Katashima, Katsuhiko Yoshimoto, \\ and Mitsuo Itakura
}

Otsuka Department of Clinical and Molecular Nutrition, The University of Tokushima, Tokushima 770, Japan

We described a method for PCR amplification of unknown flanking genomic DNA fragments. This method is a combination of PCR with "endtrimming method" and "cassettes and cassette-primers method". In this method, genomic DNA was digested with three different groups of restriction enzymes. DNA in group 1 was digested with BamHI, BgllI, Fbal, or Mbol. DNA in group 2 was digested with BInI, Nhel, Spel, or Xbal. DNA in group 3 was digested with Sall or Xhol. Digested DNA in each group was end-trimmed with Klenow fragment of DNA polymerase $I$ in the presence of only one dNTP; dGTP, dCTP, and dTTP for group 1, 2, and 3, respectively. The synthesized cassettes, C1, C2, and C3, had 5' protruding sequences of $5^{\prime}$-ATC-3', 5'-TAG-3',

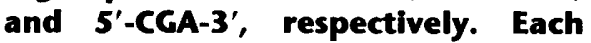
compatible cassette was ligated to the end-trimmed DNAs in group 1-3, respectively. Nested PCR was then performed using an end-trimmed and cassette-ligated DNA as a template. Primers annealing to known sequences and cassettes were used for the nested PCR. The amplified DNA fragments were electrophoresed on a polyacrylamide gel and purified. The sequences of the DNA fragments were determined after cloning into pBluescript. he PCR method, which permits specific in vitro amplification of DNA fragments, has found many applications in molecular biology. However, the PCR amplification of unknown flanking DNA fragments is difficult, because PCR requires two target-specific primers annealing to both ends of the DNA fragment to be amplified. To overcome this limitation, several methods have been developed. ${ }^{(1-10,13-15)}$

Inverse $\mathrm{PCR}^{(1)}$ involves restriction enzyme digestion and circularization by intrastrand end-to-end ligation. The following PCR using primers directing toward an unknown sequence amplifies the flanking sequence. Panhandle $\mathrm{PCR}^{(2)}$ and targeted inverted repeat amplification $^{(3)}$ involve restriction enzyme digestion of genomic DNA and ligation of a complementary oligonucleotide to the known core sequence. Denaturation and reannealing form a stem-loop within complementary strands with a $3^{\prime}$ recessed end, followed by filling with template-directed polymerization or ligation of an oligomer. The presence of an inverted repeat at two sites permits PCR amplification of the unknown flanking DNA. Anchored $\mathrm{PCR}^{(4)}$ involves attachment of a homopolymer tail to the firststrand cDNA by terminal deoxynucleotidyl transferase that undergoes templateindependent polymerization. PCR is performed using one primer annealing to a known sequence and another primer annealing to a homopolymer tail. In ligation-anchored PCR, ${ }^{(5)}$ T4 RNA ligase is used to attach a designed DNA oligomer instead of forming a homopolymer strand to the first-stand cDNA.

An end-trimming method ${ }^{(6,7)}$ amplifies a cDNA fragment using one compatible primer to a known sequence and another oligo(dT) primer. The PCR product is end-trimmed by T4 DNA polymerase in the presence of only one dNTP to create a sticky end to a corresponding vector. Cassettes and cassette-primers method, ${ }^{(7)}$ cassette-ligation mediated PCR, ${ }^{(8)}$ capture PCR, ${ }^{(9)}$ and vectorette PCR, ${ }^{(10)}$ involve restriction enzyme digestion of cDNAs or genomic DNAs and their ligation to oligonucleotides or vector sequences to create universal primerannealing sites. PCR, in these methods, utilizes one specific compatible primer to a known sequence and another universal primer that anneals to the universal sequence. Roberts et al. have successfully defined the exon structure of the entire human dystrophin gene, which consists of 79 exons, using vectorette PCR and direct sequencing. ${ }^{(11,12)}$ PCR in other methods makes use of nonspecific or partially specific primers. Targeted gene walking ${ }^{(13)}$ makes use of sets of specific and nonspecific primers to amplify an unknown flanking DNA sequence. A 
single primer was shown to be useful in cloning genomic sequences adjacent to a known sequence. ${ }^{(14)}$ Restriction-site PCR to amplify an unknown flanking sequence to a known locus was performed using a combination of a known sequence-specific primer and another primer specific to a restriction enzyme recognition sequence. ${ }^{(15)}$

We have described previously two methods of end-trimming method and cassettes and cassette-primers method to amplify adjacent cDNA fragments by PCR. ${ }^{(6,7)}$ In this paper a new method for PCR amplification of unknown flanking DNA fragments is based on a combination of end-trimming method and cassettes and cassette-primers method, which we named "PCR with end trimming and cassette ligation (ETCL-PCR)." Using this method we successfully amplified DNAs of exon-intron boundaries and a promoter region of the rat amidophosphoribosyltransferase (ATase) gene.

\section{MATERIALS AND METHODS DNA Isolation}

The rat genomic DNA was prepared from the liver of a 7-week-old male Wister rat by the standard method. ${ }^{(16)}$

\section{Synthesis of Oligomers}

We have synthesized oligomers, which are listed in Table 1, by an Applied Biosystems 392 DNA/RNA synthesizer (Foster City, CA). oRB613 is a main cassette oligomer (MC oligomer) and has two restriction enzyme recognition sites of SalI and NotI. oRB611, oRB659, and oRB658 are adaptor cassette oligomers (AC oligomers). oRB183 and oRB185, of which sequences are the same as the rat ATase cDNA, ${ }^{(7)}$ are primers annealing to the known sequence of the rat ATase gene hopefully in one coding exon, and oRB404 and oRB656 are primers annealing to cassettes.

\section{Constructing Cassettes}

Cassettes 1-3 (C1-C3) were constructed by annealing an MC oligomer of oRB613 to AC oligomers of oRB611, oRB659, or oRB658, respectively (Fig. 1). Ten nanomoles of oRB613 was mixed with 10 nmoles each of oRB611, oRB659, and oRB658 in a total volume of $100 \mu \mathrm{l}$. These mixtures were heat-denatured at $90^{\circ} \mathrm{C}$ for $3 \mathrm{~min}$ and cooled on ice for 5 min. Then, mixed oligomers annealed to each other and formed a doublestranded cassette. $\mathrm{C} 1-\mathrm{C} 3$ had the $5^{\prime}$ protruding sequences of $5^{\prime}$-ATC-3', 5'-TAG$3^{\prime}$, and $5^{\prime}-\mathrm{CGA}-3^{\prime}$, respectively.

\section{End-trimming and Cassette-ligation Method}

The flowchart of PCR with end trimming and cassette ligation is shown in Figure 2 . The case of $B \ln I$ digestion is depicted as an example. All 10 enzymes used in this study are listed in Table 2 .

\section{Step 1: Restriction Enzyme Digestion}

The rat genomic DNA $(0.5-1 \mu \mathrm{g})$ was divided into three groups. DNA in group 1 was digested with 5-10 units of BamHI

TABLE 1 Sequences of Oligomers for Constructing Cassettes and PCR Amplifications

\begin{tabular}{|c|c|c|}
\hline Names & Sequences & Notes \\
\hline oRB613 & $\begin{array}{l}5^{\prime} \text {-CCTCTTCGCTAT TA CGCCAGT CGAC } \\
\text { GCGGCCGCAAATC - } 3^{\prime}\end{array}$ & main cassette oligomer \\
\hline oRB611 & $5^{\prime}-A T C G A T T T G C G G C C A-3^{\prime}$ & adaptor cassette oligomer for $\mathrm{C} 1$ \\
\hline oRB659 & $5^{\prime}-$ TAGGAT TTGCGGCCA - 3' & adaptor cassette oligomer for $\mathrm{C} 2$ \\
\hline oRB658 & $5^{\prime}-C G A G A T T T G C G G C C A-3^{\prime}$ & adaptor cassette oligomer for $\mathrm{C} 3$ \\
\hline oRB404 & $5^{\prime}$-CCTCT TCGCT ATTACGCCAG - 3' & outer primer annealing to cassette \\
\hline oRB656 & 5'-AAT AAGTCGACGCGGCCGCAAA TC - 3' & inner primer annealing to cassette \\
\hline oRB183 & 5'-CATCTATGAGAACAA T T CT T T T GCC - $3^{\prime}$ & $\begin{array}{l}\text { outer primer annealing to the rat } \\
\text { ATase gene }\end{array}$ \\
\hline oRB185 & 5'-TTAAAGT TGTCAGACAACACGCCGA - 3' & $\begin{array}{l}\text { inner primer annealing to the rat } \\
\text { ATase gene }\end{array}$ \\
\hline
\end{tabular}

The underlined letters indicate the sequence to create restriction enzyme recognition sites for SalI and NotI. The italic letters show the $5^{\prime}$ protruding sequence complementary to the endtrimmed DNAs.

[New England BioLabs (NEB), Beverly, MA], BglII (Takara, Kyoto, Japan), FbaI (Takara), or MboI (Takara) in a buffer recommended by the manufacturer in a total volume of $30 \mu \mathrm{l}$ at $37^{\circ} \mathrm{C}$ for overnight. In the same way, DNA in group 2 was digested with 5-10 units of $B \ln \mathrm{I}$ (Takara), NheI (NEB), SpeI [Boehringer Mannheim GmbH, (BMG), Mannheim, Germany], or XbaI (BMG), and DNA in group 3 was digested with 5-10 units of SalI (NEB) or Xhol (BMG).

\section{Step 2: End Trimming}

To the restriction enzyme-digested DNA in groups $1-3$ in $30 \mu \mathrm{l}, 1 \mu \mathrm{l}$ of $5 \mathrm{~mm}$ dGTP, dCTP, or dTTP was added, respectively. Then, 2 units of Klenow fragment of DNA polymerase I (Toyobo, Osaka, Japan) in $0.5 \mu \mathrm{l}$ was added to DNA in each group and these mixtures were incubated at $30^{\circ} \mathrm{C}$ for $15 \mathrm{~min}$. Thus, restriction enzyme-digested ends of DNA in each group were end-trimmed only with $\mathrm{G}, \mathrm{C}$, or T, respectively. Klenow fragment of DNA polymerase I was inactivated by heat treatment at $75^{\circ} \mathrm{C}$ for $10 \mathrm{~min}$, followed by ethanol precipitation.

\section{Step 3: Cassette Ligation}

Ethanol-precipitated DNA in each group was ligated with 100 pmoles of C1-C3, respectively, using a DNA ligation kit (Takara) at $16^{\circ} \mathrm{C}$, from several hours to overnight in a total volume of $10 \mu \mathrm{l}$. After the ligation reaction, DNA in each group was ethanol-precipitated and dissolved in $10 \mu \mathrm{l}$ of deionized and autoclaved water (DA water).

\section{Step 4: Initial PCR Amplification}

The initial PCR amplification was performed using a pair of primers of oRB185, an outer primer designed to anneal to the rat ATase gene, and oRB404, an outer primer annealing to cassettes, and $1 \mu \mathrm{l}$ of each end-trimmed and cassette-ligated DNA as a template in a total volume of $10 \mu$ l. Because the $5^{\prime}$ ends of cassettes have no phosphate, the cassettes were ligated only to end-trimmed DNAs at their 3 ' ends. Therefore, only oRB183 could work as a primer in the first cycle of PCR, and oRB404 could work as a primer only from the second cycle of PCR. oRB611, oRB659, and oRB658 have a mismatched A at their 3' ends. Thus, they could not work as a 
ORB613 5'HO-CCTCTTCGCTATTACGCCAGTCGACGCGGCCGCAAATC-OH 3

\section{$+$}

ORB611

oRB659

oRB658

\begin{abstract}
5 ' HO-ATCGATTTGCGGCCA-OH 3 '
5 ' HO-TAGGATTTGCGGCCA-OH 3 '

5 ' HO-CGAGATTTGCGGCCA-OH 3'
\end{abstract}

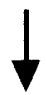

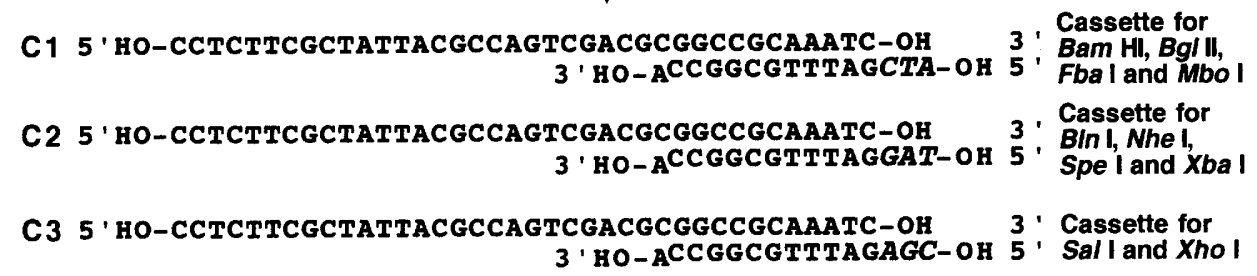

FIGURE 1 Schematic presentation of the construction of cassettes. The main cassette oligomer oRB613 was mixed with each of adaptor cassette oligomers oRB611, oRB659, and oRB658 in an equal amount in molar value. The mixtures were heat-denatured and annealed by cooling on ice. We named cassettes consisting of oRB611, oRB659, and oRB658 as C1, C2, and C3, respectively. $\mathrm{C} 1$ is a cassette for BamHI-, BgllI-, Fbal-, and Mbol-digested and end-trimmed DNAs. C2 is a cassette for BlnI-, NheI-, SpeI-, and XbaI-digested and end-trimmed DNAs. C3 is a cassette for Salland XhoI-digested and end-trimmed DNAs.

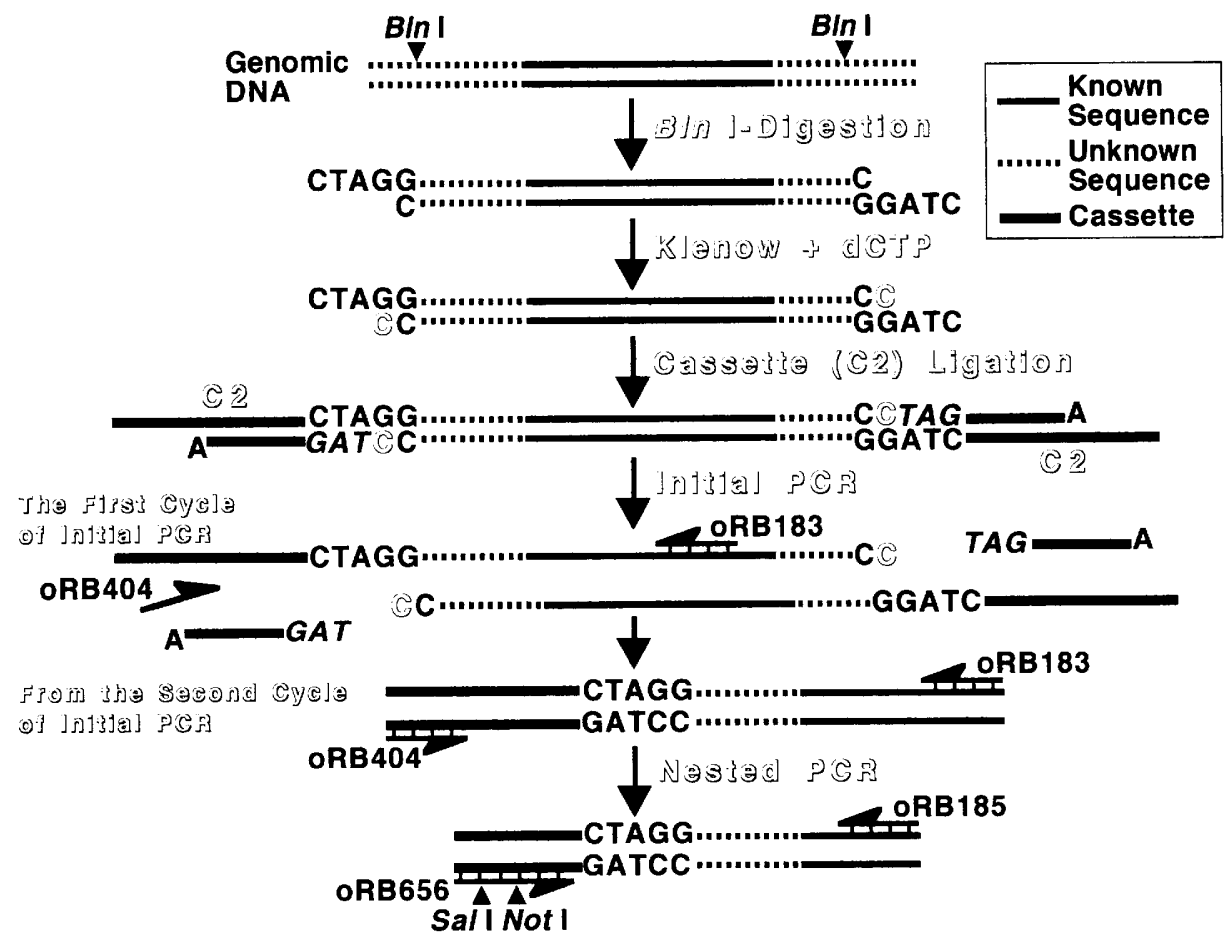

FIGURE 2 The flowchart of PCR with end trimming and cassette ligation in the case of BlnIdigestion. The rat genomic DNA was digested with BlnI and partially filled with dCTP using Klenow fragment of DNA polymerase I. C2 cassette was ligated to the BlnI-digested and endtrimmed DNA. The initial PCR was performed using oRB183, an outer primer annealing to the rat ATase gene, and oRB404, an outer primer annealing to cassette. oRB183 can work as a primer from the first cycle of the initial PCR, but oRB404 cannot work as a primer until the second cycle of the initial PCR, because the dephosphorylated 5' end of C2 is not ligated to the genomic DNA. The initial PCR product, diluted 10×, was used as a template in the nested PCR. The nested PCR was carried out using oRB185, an inner primer annealing to the rat ATase gene, and oRB656, an inner primer annealing to cassette. oRB656 has two endonuclease recognition sites of Sall and NotI. Solid lines, broken lines, and thick, bold lines indicate known sequence, unknown sequence, and cassette, respectively. primer on the cassette sequence. The PCR products of the initial PCR were diluted 10 times by DA water and used as templates in the nested PCR.

\section{Step 5: Nested PCR Amplification}

The nested PCR was performed using a pair of primers oRB183, an inner primer annealing to the rat ATase gene, and oRB656, an inner primer designed to anneal to cassettes, in a total volume of 10 $\mu \mathrm{l}$. The initial and nested PCR amplifications were performed in a mixture containing $1 \mu \mathrm{M}$ each of two primers, $200 \mu \mathrm{M}$ each of four deoxyribonucleotides, 0.025 $\mathrm{U} / \mu \mathrm{l}$ of Taq DNA polymerase (Kurabo, Osaka, Japan) in buffer containing 10 $\mathrm{mm}$ Tris- $\mathrm{HCl}\left(\mathrm{pH} 9.0\right.$ at $\left.25^{\circ} \mathrm{C}\right), 50 \mathrm{~mm}$ $\mathrm{KCl}, 1.5 \mathrm{~mm}_{\mathrm{MgCl}_{2}}$, and $0.1 \%$ Triton $\mathrm{X}-100$. Thirty cycles of the reaction at $95^{\circ} \mathrm{C}, 55^{\circ} \mathrm{C}$, and $72^{\circ} \mathrm{C}$ for 1,1 , and $3 \mathrm{~min}$, respectively, were carried out in a Program Temp Control System PC-700 (Astec, Fukuoka, Japan).

\section{Electrophoresis and Detection of PCR Products}

The PCR products of the second PCR were electrophoresed on an $8 \%$ polyacrylamide gel. The amplified DNA fragments were visualized by ethidium bromide staining and UV trans-illumination.

\section{Isolation of PCR-amplified DNA Fragments}

The DNA fragments amplified by the nested PCR were amplified again using the same set of primers and template at a scaled-up volume of $50 \mu \mathrm{l}$. To remove overhanging nucleotide added by Taq DNA polymerase at the $3^{\prime}$ end, 2 units of Klenow fragment of DNA polymerase I was added to the reaction mixture and incubated at $30^{\circ} \mathrm{C}$ for $20 \mathrm{~min}$. Electrophoresis was performed on an $8 \%$ polyacrylamide gel, and DNAs were visualized with ethidium bromide staining and UV trans-illumination. The amplified DNA fragments were cut out and extracted by the "crush and soak" method with slight modification as described previously. ${ }^{(17)}$ The recovered DNA was dissolved in $50 \mu$ l of DA water and quantitated using a DU-64 spectrophotometer (Beckman, Fullerton, CA). 
TABLE 2 Combinations of Restriction Enzymes and Cassettes Applicable for PCR with End Trimming and Cassette Ligation

\begin{tabular}{|c|c|c|c|c|c|c|}
\hline $\begin{array}{l}\text { Restriction } \\
\text { enzymes }\end{array}$ & $\begin{array}{l}\text { Restriction } \\
\text { sequences }\end{array}$ & $\begin{array}{l}\text { Enzyme } \\
\text { digestion }\end{array}$ & $\begin{array}{l}\text { End } \\
\text { trimming }\end{array}$ & & $\begin{array}{l}\text { Cassettes } \\
\text { and their } \\
5^{\prime} \text { ends }\end{array}$ & \\
\hline BamHI & $\begin{array}{l}5^{\prime} \text {-GGA T CC-3' } \\
3^{\prime}-\text { CCT AGG-5' }\end{array}$ & $\begin{array}{l}5^{\prime}-\mathrm{G} \\
3^{\prime}-\mathrm{CCTAG}-5^{\prime}\end{array}$ & $\begin{array}{l}5^{\prime}-\mathrm{GG} \\
3^{\prime}-\mathrm{CCTAG}-5^{\prime}\end{array}$ & \multirow{4}{*}{+} & \multirow{4}{*}{$\begin{array}{r}5^{\prime}-\mathrm{ATCG}-\mathbf{3}^{\prime} \\
\mathrm{C}---5^{\prime}\end{array}$} & \multirow{4}{*}{ C1 } \\
\hline BgllI & $\begin{array}{l}5^{\prime}-\text { AGATCT }-3^{\prime} \\
3^{\prime} \text {-TCT AGA }-5^{\prime}\end{array}$ & $\begin{array}{l}5^{\prime}-\mathrm{A} \\
3^{\prime}-\mathrm{TCTAG}-5^{\prime}\end{array}$ & $\begin{array}{l}5^{\prime}-A G \\
3^{\prime}-\mathrm{TCTAG}-5^{\prime}\end{array}$ & & & \\
\hline FbaI & $\begin{array}{l}5^{\prime}-\text { TGATCA-3' } \\
3^{\prime} \text {-ACTAGT-5' }\end{array}$ & $\begin{array}{l}5^{\prime}-\mathrm{T} \\
3^{\prime}-\mathrm{ACTAG}-5^{\prime}\end{array}$ & $\begin{array}{l}5^{\prime}-\mathrm{TG} \\
3^{\prime}-\mathrm{ACT} A G-5^{\prime}\end{array}$ & & & \\
\hline MboI & $\begin{array}{l}5^{\prime}-\text { GATC }--3^{\prime} \\
3^{\prime}-\text { CT AG }--5^{\prime}\end{array}$ & $\begin{array}{l}5^{\prime}-- \\
3^{\prime}-- \text { CTAG-5' }\end{array}$ & $\begin{array}{l}5^{\prime}-\text { - G } \\
3^{\prime}-\text { - CTAG-5' }\end{array}$ & & & \\
\hline$B \ln \mathrm{I}$ & $\begin{array}{l}5^{\prime}-\text { CCT AGG-3' } \\
3^{\prime} \text {-GGAT CC-5' }\end{array}$ & $\begin{array}{l}5^{\prime}-\mathrm{C} \\
3^{\prime}-\mathrm{GGATC}-5^{\prime}\end{array}$ & $\begin{array}{l}5^{\prime}-\mathrm{CC} \\
3^{\prime}-\mathrm{GGATC}-5^{\prime}\end{array}$ & & & \multirow{4}{*}{$\mathrm{C} 2$} \\
\hline NheI & $\begin{array}{l}5^{\prime} \text {-GCTAGC-3' } \\
3^{\prime} \text {-CGAT CG-5' }\end{array}$ & $\begin{array}{l}5^{\prime}-\mathrm{G} \\
3^{\prime}-\mathrm{CGATC}-5^{\prime}\end{array}$ & $\begin{array}{l}5^{\prime}-\mathrm{GC} \\
3^{\prime}-\mathrm{CGATC}-5^{\prime}\end{array}$ & + & $5^{\prime}-$ TAGG$^{--3^{\prime}}$ & \\
\hline SpeI & $\begin{array}{l}5^{\prime}-\text { ACT AGT-3' } \\
3^{\prime} \text {-TGATCA-5' }\end{array}$ & $\begin{array}{l}5^{\prime}-\mathrm{A} \\
3^{\prime}-\mathrm{TGATC}-5^{\prime}\end{array}$ & $\begin{array}{l}5^{\prime}-A C \\
3^{\prime}-T_{G A T C} 5^{\prime}\end{array}$ & & C---5 & \\
\hline XbaI & $\begin{array}{l}5^{\prime} \text {-TCT AGA-3' } \\
3^{\prime} \text {-AGATCT-5' }\end{array}$ & $\begin{array}{l}5^{\prime}-\mathrm{T} \\
3^{\prime} \text {-AGATC-5' }\end{array}$ & $\begin{array}{l}5^{\prime}-\mathrm{TC} \\
3^{\prime}-\mathrm{AGATC}-5^{\prime}\end{array}$ & & & \\
\hline Sall & $\begin{array}{l}5^{\prime}-\text { GTCGAC-3' } \\
3^{\prime}-\mathrm{CAGCTG}-5^{\prime}\end{array}$ & $\begin{array}{l}5^{\prime}-\mathrm{G} \\
3^{\prime}-\mathrm{CAGCT}-5^{\prime}\end{array}$ & $\begin{array}{l}5^{\prime}-\mathrm{GT} \\
3^{\prime}-\mathrm{CAGCT}-5^{\prime}\end{array}$ & + & $5^{\prime}-\mathrm{CGAG}-3^{\prime}$ & \multirow{2}{*}{ C3 } \\
\hline XhoI & $\begin{array}{l}5^{\prime}-\mathrm{CTCGAG}-3^{\prime} \\
3^{\prime}-\mathrm{GAGCTC}-5^{\prime}\end{array}$ & $\begin{array}{l}5^{\prime}-\mathrm{C} \\
3^{\prime}-\mathrm{GAGCT}-5^{\prime}\end{array}$ & $\begin{array}{l}5^{\prime}-\mathrm{CT} \\
3^{\prime}-\mathrm{GAGCT}-5^{\prime}\end{array}$ & & C---5' & \\
\hline
\end{tabular}

\section{Cloning of PCR Products}

The amplified DNA fragment (0.01-0.02 $\mu g$ ) was digested with 5 units of NotI manufacturer in a total volume of $10 \mu \mathrm{l}$. pBluescript II SK $(+)(0.1 \mu g$; Stratagene, La Jolla, CA) was digested with 5 units of NotI and EcoRV (Takara) in the buffer (BMG) in the buffer recommended by a recommended by the manufacturer in a total volume of $10 \mu$ l. The restriction enzyme-digested DNA fragment and pBluescript were combined and ethanol-precipitated. The DNA fragment and pBluescript were ligated using a DNA ligation kit (Takara) in a total volume of 6 $\mu \mathrm{l}$. The competent JM109 cell was transformed with recombinant pBluescript.

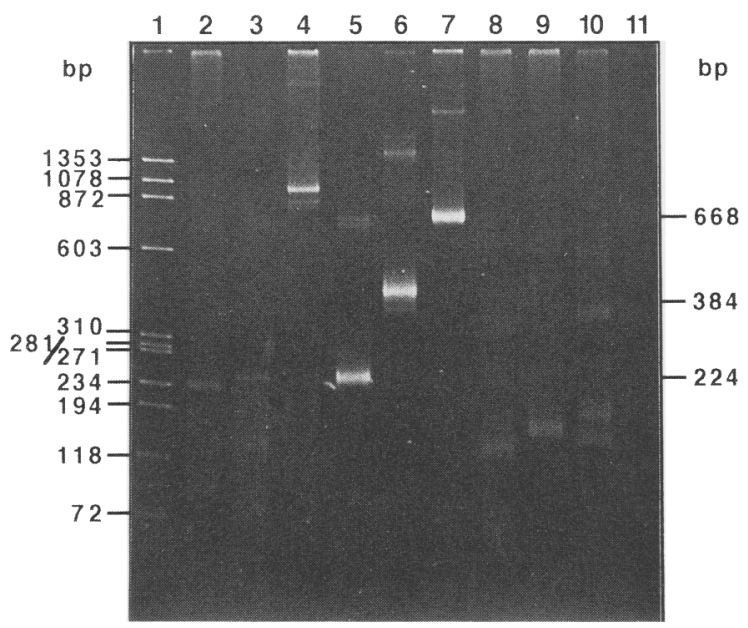

FICURE 3 A gel image of the nested PCR products. The nested PCR was performed using oRB185 and oRB656, and its products were electrophoresed on an $8 \%$ polyacrylamide gel and visualized with ethidium bromide staining and UV trans-illumination. (Lane 1) DNA size markers of HaeIIIdigested $\phi \times 174$; (lanes 2-11) the nested PCR products starting from BamHI-, BglII-, FbaI-, MboI-, $B l n I-$, NheI-, SpeI-, XbaI-, SalI-, and XhoI-digested and end-trimmed DNAs, respectively.
Plasmid DNA was prepared by a smallscale alkaline lysis method. ${ }^{(18)}$

\section{Nucleotide Sequencing and Computer-Aided Analysis}

Nucleotide sequence was determined using the Taq Dye Primer Cycle Sequencing Core Kit (401112) in the ABI 373A sequencer. Cloned pBluescript was used as a template. The nucleotide sequence identity between the rat ATase cDNA and part of newly cloned genomic DNA was analyzed using the SDC-GENETYX version 8.0 program (SDC, Tokyo, Japan).

\section{RESULTS}

As shown in Figure 1, constructed cassettes of $\mathrm{C} 1-\mathrm{C} 3$ have the $5^{\prime}$ protruding sequences of $5^{\prime}$-ATC-3', 5'-TAG-3', and $5^{\prime}$-CGA-3', respectively. Because these cassettes have no phosphate at the 5' end and their ends are not complementary to each other, they never ligate to themselves.

DNA in group 1 was digested with $B a m H I, B g l I I, F b a I$, or $M b o I$ and endtrimmed by partial filling with dGTP using Klenow fragment of DNA polymerase I. Their ends are complementary to $\mathrm{C} 1$ but not to themselves (Table 2). In the same way, DNA in group 2 was digested with $B \ln \mathrm{I}$, NheI, SpeI, or XbaI and partially filled with dCTP with their ends complementary to C2 (Table 2). The SalIor Xhol-digested and dTTP-filled DNAs in group 3 have complementary ends to C3 (Table 2).

Figure 3 shows the results of an amplified exon-intron boundary of the rat ATase gene by ETCL-PCR. The rat genomic DNA isolated from the liver was digested with BamHI, BglII, FbaI, MboI, BlnI, NheI, SpeI, XbaI, SalI, or XhoI. Each of restriction enzyme-digested DNAs was end-trimmed and cassette-ligated appropriately. The initial PCR amplification was performed with a pair of primers of oRB183 and oRB404 using end-trimmed and cassette-ligated DNA as a template. The nested PCR was performed with a pair of primers of oRB185 and oRB656 using an initial PCR product diluted 10 times as a template. Lanes $2-11$ of Figure 3 show the results from BamHI-, BglII-, FbaI-, MboI-, BlnI-, NheI-, SpeI-, XbaI-, Sall-, and XhoI-digested DNA, respectively. Lanes 5-7 show promising bands.

The DNA fragments of lanes 6 and 7 of Figure 3 were amplified again in 
scaled-up volume of $50 \mu \mathrm{l}$ and isolated by the slightly modified crush and soak method. The isolated DNA fragments were cloned into NotI and EcoRV doubledigested pBluescript, and the nucleotide sequences were determined (Figs. 4 and 5). As shown in Figure 4 (top), C2 was ligated to the BlnI-digested and dCTPfilled DNA fragment. C2, as shown in Figure 4 (bottom), was also ligated to the NheI-digested and dCTP-filled DNA fragment.

Figure 5 shows the alignment of the nucleotide sequence cloned by ETCLPCR from the rat genomic DNA with that of the rat ATase cDNA. The sequence from 535 to 665 of the newly cloned DNA was identical with that of the rat ATase cDNA, whereas its 5'-end sequence differed from the sequence of the rat ATase cDNA. The starting boundary sequence in the unmatched sequence was AG, which was the consensus sequence of mRNA splicing acceptor site. This result suggested that an exonintron boundary of the rat ATase gene was successfully cloned by ETCL-PCR.

Moreover, the newly cloned DNA contained the connected sequence of $\mathrm{C} 2$ and NheI recognition site and endonuclease recognition sites of $B \ln \mathrm{I}$ and $\mathrm{MboI}$. Therefore, it proved that the bands shown in lanes 5-7 of Figure 3 were specifically amplified by ETCL-PCR.

\section{DISCUSSION}

In this paper we have described a method of ETCL-PCR. Several other methods to PCR-amplify unknown flanking DNA fragments involve restriction enzyme digestion followed by a ligation reaction, ${ }^{(1-3,7-10)}$ but the generation of concatemers is a problem in those methods. To avoid concatemer formation, dephosphorylation by calf intestinal alkaline phosphatase or redigestion after ligation of oligomers was performed but a restriction enzyme recognition site was not completely reconstructed. ${ }^{(2,3)}$ We used several tactics to prevent concatemer formation in ETCLPCR. First, the end-trimmed DNA in our method does not ligate to itself, because genomic DNA is digested with a restriction endonuclease and partially filled with only one kind of dNTP using Klenow fragment of DNA polymerase I. Second, each synthesized cassette also does not self-ligate, because it has no phosphates at the $5^{\prime}$ ends and no complementary ends to itself. Because of these characteristics, the end-trimmed DNA is expected to exclusively ligate to a compatible cassette.

Another merit of ETCL-PCR is its specific amplification of the desired DNA fragment. Because the $5^{\prime}$ end of a cassette has no phosphate, a cassette ligates only to an end-trimmed DNA at the 3' end of an MC oligomer of oRB613. In the initial PCR, a primer targeted to a known
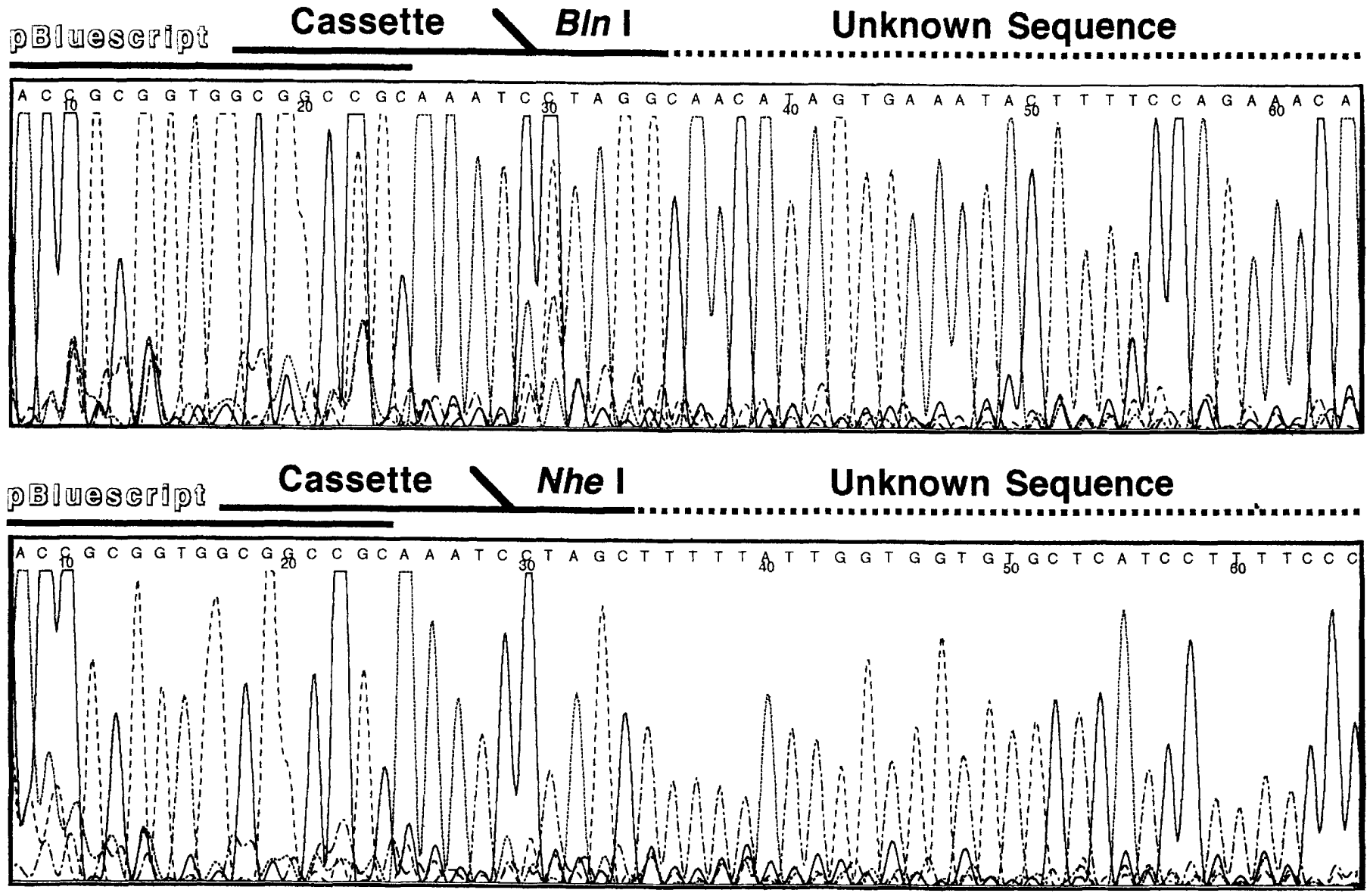

FIGURE 4 Nucleotide sequences of the DNA fragments amplified by ETCL-PCR. (Top) ETCL-PCR was started from the rat genomic DNA, which was BlnI-digested, end-trimmed with ACTP, and ligated to C2. The nested PCR product was cloned into pBluescript, and the nucleotide sequence analysis was performed. (Bottom) The rat genomic DNA, which was Nhel-digested, end-trimmed with dCTP, and ligated to C2, was subjected to the initial and nested PCR and cloned into pBluescript. Nucleotide sequencing was performed using the recombinant pBluescript as a template. 


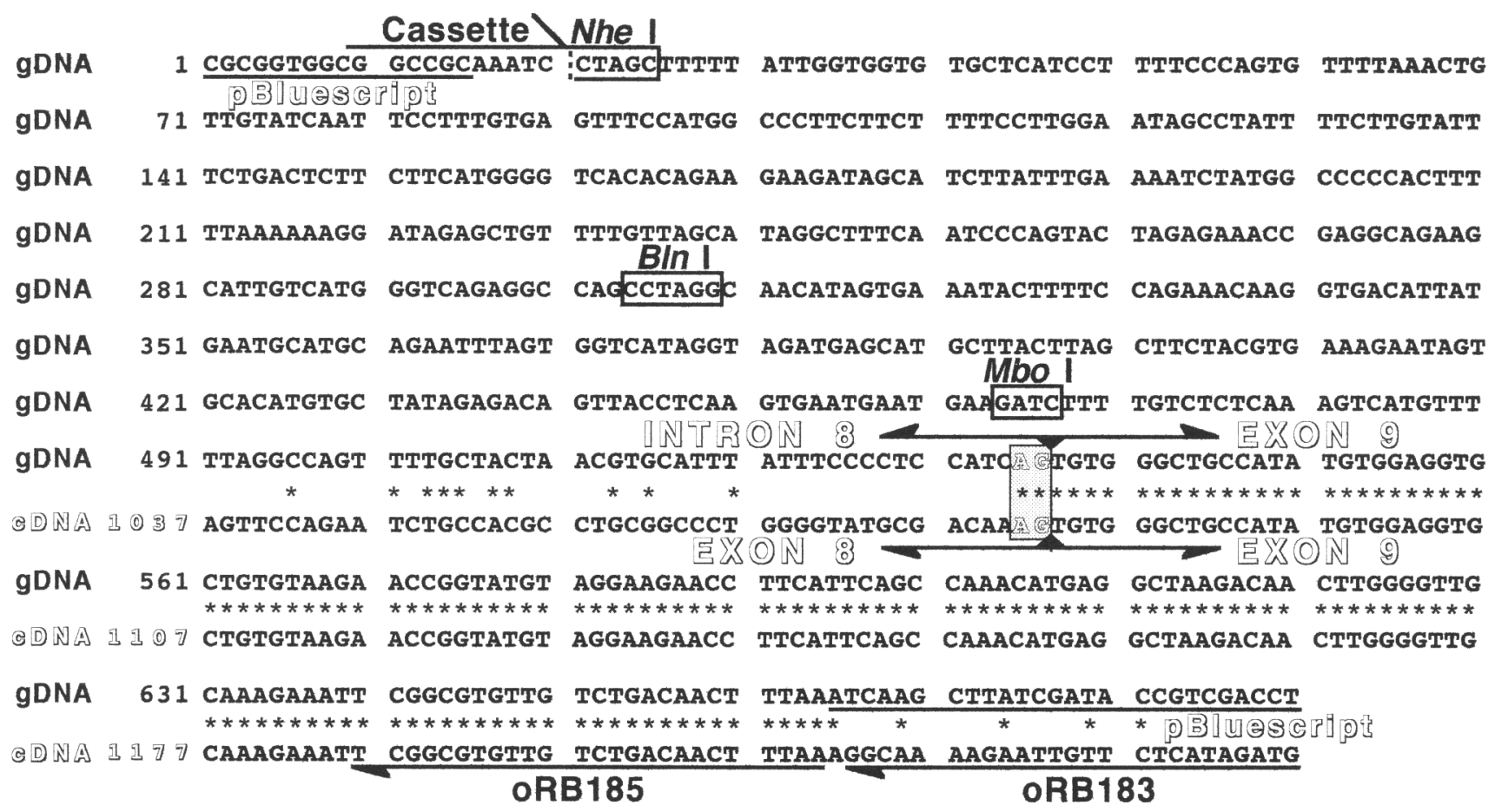

FIGURE 5 Alignment of the nucleotide sequence of newly cloned DNA by ETCL-PCR with that of the rat ATase cDNA. Asterisks ( $\left.{ }^{*}\right)$ indicate the identical nucleotide between these two sequences. gDNA and cDNA indicate the newly cloned DNA from the rat genomic DNA and the rat ATase cDNA, respectively. The nucleotide sequence of the gDNA is numbered arbitrarily and that of the rat ATase cDNA is numbered as described by Iwahana et al. ${ }^{(7)}$ The common DDBJ, EMBL, and GenBank accession number of the rat ATase cDNA is D10853.

sequence can work from the first cycle of PCR, whereas a complementary primer to a cassette can work only from the second cycle of PCR. Therefore, a DNA fragment, which elongates from a primer annealing to a known sequence, is the only specific fragment to be amplified. Another small tip is a mismatched $A$ at the $3^{\prime}$ end of an AC oligomer that inhibits it from annealing to a cassette as a PCR primer. Because oRB656, a complementary primer to a cassette, has Sall and NotI recognition sites, the PCR-amplified DNA fragments can easily be cloned into a plasmid such as pBluescript.

The average sizes of DNA fragments produced by 4- or 6-bp recognition restriction enzymes are theoretically estimated as $4^{4}=256$ bp or $4^{6}=4096 \mathrm{bp}$, respectively. We used one 4-bp cutter and nine different 6-bp cutters (Table 2). Therefore, it is estimated that there is one 4-bp cutter recognition site in every $256 \mathrm{bp}$ and there is one 6-bp cutter recognition site in every $4096 / 9=455$ bp, on average. Thus, the probability of amplifying a DNA fragment using ETCLPCR with these 10 different restriction endonucleases is very high. The possibility that the designed primer overcrosses an exon-intron boundary could be overcome by using multiple primers.

Following our previous cloning of rat ATase CDNA, ${ }^{(7)}$ ETCL-PCR was applied to amplify the intron sequences flanking the exons of the rat ATase gene. As shown in Figure 3, three DNA fragments of 668,384 , and 224 bp were clearly amplified by ETCL-PCR using primers oRB183 and oRB185, which annealed to the known rat ATase CDNA sequence. Nucleotide sequencing of these DNA fragments revealed that a cassette, $\mathrm{C} 2$, was ligated at the sites of $B \ln \mathrm{I}$ and NheI as expected (Fig. 4). The alignment of nucleotide sequences of the amplified DNA fragments and the rat ATase cDNA showed that sequence mismatch starts from the sequence of $A G$, which is a consensus sequence of an acceptor site of mRNA splicing (Fig. 5). Using ETCL-PCR and ordinary PCR we successfully amplified 20 exon-intron boundaries and a promoter region of the rat ATase gene. ${ }^{(19)}$ On the basis of the compiled result, the genomic DNA sequence of rat ATase consists of 11 exons and all exonintron boundaries conform to the consensus splice junctions. oRB183 and oRB185 anneal to the sequence of exon
9, and the amplified DNA fragments contain the boundary of intron 8 and exon 9 (Fig. 5).

The ETCL-PCR is useful because (1) an end-trimmed DNA and a cassette do not self-ligate and (2) a DNA fragment, which elongates from a primer annealing to a known sequence, is the only specific fragment to be amplified; moreover, (3) changing the $5^{\prime}$ end sequence of AC oligomers makes it possible to apply ETCL-PCR to other restriction enzymes, which produce the $5^{\prime}$ end overhang, in addition to those stated in this report.

\section{ACKNOWLEDGMENTS}

This study was supported in part by a grant from Otsuka Pharmaceutical Factory, Inc., for Otsuka Department of Clinical and Molecular Nutrition, School of Medicine, The University of Tokushima. We thank Kyo Adzuma and Yoko Takahashi for excellent technical assistance.

\section{REFERENCES}

1. Ochman, H., A.S. Gerber, and D.L. Hartl. 
1988. Genetic applications of an inverse polymerase chain reaction. Genetics 120: $621-623$.

2. Jones, D.H. and S.C. Winistorfer. 1993. Genome walking with 2- to 4-kb steps using panhandle PCR. PCR Methods Applic. 2: 197-203.

3. Jones, D.H. and S.C. Winistorfer. 1993. A method for the amplification of unknown flanking DNA: Targeted inverted repeat amplification. BioTechniques 15: 894-904.

4. Loh, E.Y., J.F. Elliott, S. Cwirla, L.L. Lanier, and M.M. Davis. 1989. Polymerase chain reaction with single-sided specificity: Analysis of T cell receptor $\delta$ chain. Science 243: $217-220$.

5. Troutt, A.B., M.G. McHeyzer-Williams, B. Pulendran, and G.J.V. Nossal. 1992. Ligation-anchored PCR: A simple amplification technique with single-sided specificity. Proc. Natl. Acad. Sci. 89: 9823-9825.

6. Iwahana, H., N. Mizusawa, S. Ii, K. Yoshimoto, and M. Itakura. 1994. An end-trimming method to amplify adjacent cDNA fragments by PCR. BioTechniques 16: 9498.

7. Iwahana, H., T. Yamaoka, M. Mizutani, N. Mizusawa, S. Ii, K. Yoshimoto, and M. Itakura. 1993. Molecular cloning of rat amidophosphoribosyltransferase. J. Biol. Chem. 268: 7225-7237.

8. Isegawa, Y., J. Sheng, Y. Sokawa, K. Yamanishi, O. Nakagomi, and S. Ueda. 1992. Selective amplification of cDNA sequence from total RNA by cassette-ligation mediated polymerase chain reaction (PCR): Application to sequencing $6.5 \mathrm{~kb}$ genome segment of hantavirus strain B-1. Mol. Cell. Probes 6: 467-475.

9. Lagerström, M., J. Parik, H. Malmgren, J. Stewart, U. Pettersson, and U. Landegren. 1991. Capture PCR: Efficient amplification of DNA fragments adjacent to a known sequence in human and YAC DNA. PCR Methods Applic. 1: 111-119.

10. Arnold, C. and I.J. Hodgson. 1991. Vectorette PCR: A novel approach to genomic walking. PCR Methods Applic. 1: 39-42.

11. Roberts, R.G., A.J. Coffey, M. Bobrow, and D.R. Bentley. 1992. Determination of the exon structure of the distal portion of the dystrophin gene by vectorette PCR. Genomics 13: 942-950.

12. Roberts, R.G., A.J. Coffey, M. Bobrow, and D.R. Bentley. 1993. Exon structure of the human dystrophin gene. Genomics 16: 536-538.

13. Parker, J.D., P.S. Rabinovitch, and G.C. Burmer. 1991. Targeted gene walking polymerase chain reaction. Nucleic Acids Res. 19: 3055-3060.

14. Parks, C.L., L.-S. Chang, and T. Shenk. A polymerase chain reaction mediated by a single primer: Cloning of genomic sequences adjacent to a serotonin receptor protein coding region. Nucleic Acids Res.
19: $7155-7160$.

15. Sarkar, G., R.T. Turner, and M.E. Bolander. 1993. Restriction-site PCR: A direct method of unknown sequence retrieval adjacent to a known locus by using universal primers. PCR Methods Applic. 2: 318-322.

16. Blin, N. and D.M. Stafford. 1976. A general method for isolation of high molecular weight DNA from eukaryotes. Nucleic Acids Res. 3: 2303-2308.

17. Iwahana, H., K. Yoshimoto, T. Tsujisawa, and M. Itakura. 1994. T-cassette ligation: A method for direct sequencing and cloning of PCR-amplified DNA fragments. PCR Methods Applic. 3: 219-224.

18. Sambrook, J., E.F. Fritsch, and T. Maniatis. 1989. Small-scale preparations of plasmid DNA. In Molecular cloning: A laboratory manual, 2nd ed., pp. 1.25-1.30. Cold Spring Harbor Laboratory Press, Cold Spring Harbor, New York.

19. Honda, S., H. Iwahana, T. Tsujisawa, Y. Takahashi, K. Adzuma, R. Katashima, T. Yamaoka, K. Yoshimoto, and M. Itakura, in prep.

Received March 7, 1994; accepted in revised form April 28, 1994. 


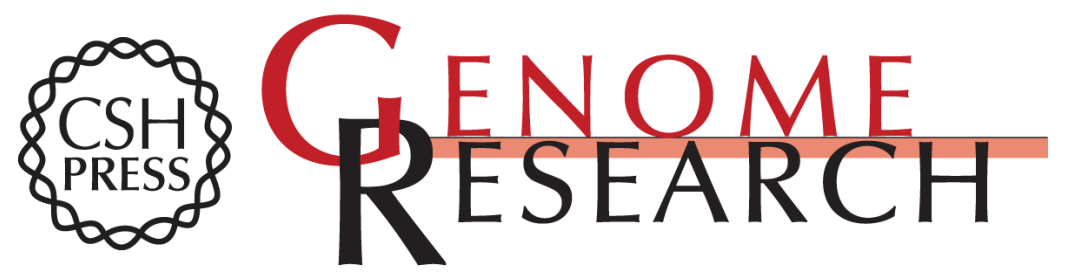

\section{PCR with end trimming and cassette ligation: a rapid method to clone exon-intron boundaries and a 5'-upstream sequence of genomic DNA based on a cDNA sequence.}

H Iwahana, T Tsujisawa, R Katashima, et al.

Genome Res. 1994 4: 19-25

References This article cites 16 articles, 4 of which can be accessed free at: http://genome.cshlp.org/content/4/1/19.full.html\#ref-list-1

\section{License}

Email Alerting Service

Receive free email alerts when new articles cite this article - sign up in the box at the top right corner of the article or click here.

\section{Affordable, Accurate Sequencing.}

